
${ }^{N} 6 / 6^{47}$ April 23, 1949
Chemical Architecture

Edited by R. E. Burk and Oliver Grummitt. (Frontiers in Chemistry, Vol. 5.) Pp. $x+202$. (New York and London: Interscience Publishers, Inc., 1948.) 4.50 dollars; $27 s$.

$\mathrm{T}$ HE Western Reserve University in Cleveland, Ohio, has established a reputation for series of lectures in what is usefulf termed the "Frontiers of Chemistry". These leatures deal with a variety of topics of currennofferest. In an expanded and therefore more alceptable form they have been published at ind fals during the past few years. This is the ffth volume of the series. The need for reviews of thif kind is perhaps more pressing than in normal times because few chemists have had the opportunity of writing monographs on those branches of chemistry in an active state of development.

Under the all-embracing title of this book many topics are discussed by a number of eminent chemists of the United States. In every case the lecture has been much expanded and fully documented, so that each article is an up-to-date and complete summary of the particular line of investigation. Dr. H. S. Taylor leads off with a generally discursive article on the influence of molecular geometry in reaction mechanism, particular attention being paid to heterogeneous reactions where molecular geometry is often of overriding importance. Dr. C. P. Smyth appropriately discusses the more recent contributions that dipole measurements have brought to the elucidation of the structure of a number of molecules in which the method is of particular value. There is a more than usually complete survey of the structure of co-ordination compounds by Dr. W. C. Fernelius. To go to the other extreme of difficulty, Dr. B. E. Warren deals with the important contribution X-ray diffraction studies have made to measuring the degree of disorder and of short-range order in substances like carbon black and certain alloys; and Dr. M. W. Tamele deals with the difficult problem of the structure of gels used as a substratum for the production of catalysts. The longest article, on "Light Scattering in Polymer Solutions", by Dr. H. Mark, is particularly opportune. There has been much talk and a great deal of experimenting with light scattering but not nearly enough published matter, theoretical or experimental. This article will be especially useful to all those interested in this important method.<smiles>[GeH3]</smiles>

H. W. Melville

Pohledy do nebe

Problémy a výsledky moderní astronomie. Napsal Dr. Hubert Slouka. Pp. $460+43$ plates. (Praha: Nakladatelství Orbis, 1947.) 165 Kčs. In Czech. (Exploring the Skies: problems and results of modern astronomy. By Dr. Hubert Slouka. Prague : Orbis, 1947.)

THIS recent astronomy book by the Czech 1 astrongmen Dr. H. Slouka, aims at introducing a wide publofe some of the most interesting astronomice ploblems of to-day. It is not intended as a to tobok but rather to stimulate a more specialized st phy of its large variety of subjects. It falls into eight main chapters: the road to the stars; telescopes of to-day and to-morrow; the sun; the world of the planets; celestial wanderers; the world of the stars and nebulæ; beyond the Milky Way; and the birth and death of worlds. Tables of astronomical data are added as well as a useful bibliographical list. Many of the illustrations are drawings new to books of this kind; in addition, some forty plates are well chosen and beautifully reproduced. The first two editions of the book were published in Prague in 1942, and the author's remarks bear witness to the difficulties of the time in which he worked at it. The book is very vividly written in a manner which the author hopes will help "to win for astronomy new and enthusiastic friends who will strive for this most attractive of all sciences to penetrate to all sections of the public".

A. B.

\section{An Introduction to Mathematics}

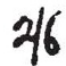

By Dr. A. N. Whitehead. (Home University Library of Modern Knowledge, No. 18.) Twelfth impression. Pp. v+192. (London: Oxford University Press, 1948). 5s. net.

7 HAT the late Prof. A. N. Whitehead's little volume should ablish itself as a classic is not surprising. If An published in the "Home University Ifibra ry" in 1911, was reprinted about eight tivest and finally was reset in its present form in 1948 under the supervision of Prof. J. H. C. Whitehead, of Oxford, the late author's nephew. The diagrams have been re-drawn; but apart from the correction of inaccuracies and typographical errors, the author's original wording has, in no instance, been altered. In the reset edition the number of pages has been reduced from 256 to 191; but the text is still quite clear and readable. In seeking to explain the nature of mathematics, it still affords a very interesting account of how mathematics forms the background of all science.

\section{Asparagus}

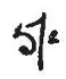

By Alfred W. Kidner. Pp. $168+17$ plates. (London : Faber and Faber, Ltd., 1947.) 15s. net.

7 .

HAT delectable vegetable, asparagus, has been cultivated by maror more than two thousand years ; the elde to to speaks of its cultivation, and it may bo/hresumed that it was known and grown lon bef 3 that time. Yet in all this long time it has fonged little in its character, and, as the author of thy book points out, no really fixed and distinct forms or varieties have been produced. It is strange that so esteemed a luxury should never have received much attention from plant-breeders. Largely through chance, Mr. A. W. Kidner took up the problem of selection and breeding of giant forms of asparagus, and through long years of empirical observation, isolation and cross-fertilization developed strains of superlative quality. There is no doubt of the success that has attended his efforts, and they show what might still be done if the genetics of the plant were really worked out and strains homozygous for the desirable qualities fixed.

The author lays no claim to being a man of science, and throughout the work there runs a curious implication almost of surprise that asparagus should respond to controlled breeding methods-a suggestion of pleading a case that special laws operate in this one instance and that it may be difficult to convince the reader of the value of breeding. In this respect, the book is needlessly repetitive; but, as an otherwise straightforward account of how the practical man can go about developing his own super-quality strains and how to grow and market them, the book is of great value. It should certainly stimulate the new National Vegetable Research Station, when it begins operations, to take up the study of the genetics of asparagus.
R. H. Stoughton 